http://kitaibelia.unideb.hu/

ISSN 2064-4507 (Online) • ISSN 1219-9672 (Print)

(C) 2015, Department of Botany, University of Debrecen, Hungary

21 (1): 101-115.; 2015

DOI: $10.17542 /$ kit.21.101

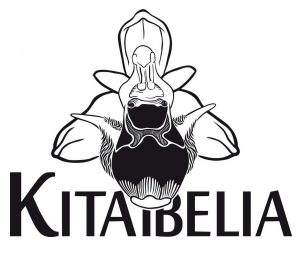

\title{
Pótlások a Magyarország edényes növényfajainak elterjedési atlaszához I.
}

\author{
TAKÁCS Attila1* ${ }^{*}$ NAGY Timea ${ }^{2}$, SRAMKó Gábor ${ }^{1}$, LoVAS-KISS Ádám¹, \\ SÜVEGES Kristóf ${ }^{1}$, LUKÁCS Balázs András ${ }^{3}$, FEKETE Réka ${ }^{1}$, LÖKI Viktor ${ }^{1}$, MALATINSZKY Ákos ${ }^{4}$, \\ E. VojtKó Anna ${ }^{3}$, Koscsó János 5 , Pfliegler Walter Péter ${ }^{6}$, \\ NóTÁRI Krisztina ${ }^{1} \&$ MOLNÁR V. Attila ${ }^{1}$
}

(1) Debreceni Egyetem TTK Növénytani Tanszék, H-4032 Debrecen, Egyetem tér 1.; *limodorum.abortivum@gmail.com

(2) Pannon Egyetem GK Növénytudományi és Biotechnológiai Tanszék, H-8360 Keszthely, Festetics u. 7. (3) Magyar Tudományos Akadémia, Ökológiai Kutatóközpont, Tisza-kutató Osztály, H-4026, Debrecen, Bem tér 18/C.

(4) Szent István Egyetem MKK Természetvédelmi és Tájgazdálkodási Intézet, Természetvédelmi és Tájökológiai Tanszék, H-2103 Gödöllő, Páter K. u. 1.

(5) H-3529 Miskolc, Sályi István u. 16.

(6) Debreceni Egyetem TTK Biotechnológiai és Mikrobiológiai Tanszék, H-4032 Debrecen, Egyetem tér 1.

\section{Contributions to the Atlas Florae Hungariae I.}

\begin{abstract}
The main aim of the present work is to contribute with new data to the distribution maps published recently in Atlas Florae Hungariae. Occurrence data of 297 vascular plant taxa from 247 flora mapping quarter quadrates (CEU) are presented. This floristic paper is somehow unusual because besides the occurrence data of rare or sporadic taxa (e.g. Armoracia macrocarpa (Waldst. et Kit.) Kit. ex Baumg., Samolus valerandi L., Epipactis voethii Robatsch), frequent, but more or less underrepresented taxa (e.g. Ranunculus ficaria L., Viola kitaibeliana Roem. et Schult., Gagea villosa (M. Bieb.) Duby), as well as alien taxa (e.g. Cymbalaria muralis G. Gaertn., B. Mey. et Scherb., Potentilla indica (Andrews) Focke, Tragus racemosus (L.) All.) are also enumerated, since our intention was to fill the - sometimes evident - gaps in the Atlas. The name initials of the author(s) who actually found the given occurrence are presented in brackets at each record.
\end{abstract}

Keywords: distribution data, flora mapping, flora of Hungary, vascular flora

Összefoglalás - Közleményünk célja a Magyarország edényes növényfajainak elterjedési atlasza térképeinek kiegészítése, főként aktuális előfordulási adatokkal. Összesen 297 edényes taxon előfordulási adatait közöljük az ország egész területéről, mintegy 247 flóratérképezési negyedkvadrátból. Az adatok között a ritkább taxonok (például Armoracia macrocarpa (Waldst. et Kit.) Kit. ex Baumg., Samolus valerandi L., Epipactis voethii Robatsch) mellett országosan elterjedt, de többékevésbé adathiányos fajok (például Ranunculus ficaria L., Viola kitaibeliana Roem. et Schult., Gagea villosa (M. Bieb.) Duby), illetve adventív fajok (például Cymbalaria muralis G. Gaertn., B. Mey. et Scherb., Potentilla indica (Andrews) Focke, Tragus racemosus (L.) All.) esetében is közöljük az atlasz térképeihez képest újnak bizonyuló lelőhelyeket.

Kulcsszavak: edényes flóra, elterjedési adatok, flóratérképezés, Magyarország flórája 


\section{Bevezetés}

A XI. Aktuális Flóra- és Vegetációkutatás a Kárpát-medencében konferencián vehettük kézbe a Magyarország edényes növényfajainak elterjedési atlaszát (BARTHA et al. 2015). A várva várt mű elsősorban 171 fő terepi felmérő 2002-2014 közötti munkáján, kisebb részben (mintegy 100 faj esetében) herbáriumi és (KEF-kóddal publikált adatok bevonásával) irodalmi feldolgozáson alapul. A Flóraatlaszban közzétett adattömeg nem csak florisztikai és növényföldrajzi szempontból figyelemreméltó, hanem például ökológiai vagy konzervációbiológiai kutatásoknak is hasznos információforrása lesz (PócS 2016). Kiértékelésének lehetőségei szinte végtelenek (vö. KuLL et al. 2002, FEKETE 2011, KAPLAN et al. 2015, KAPLAN et al. 2016). A mű ráadásul nemzetközi kitekintésben is nagy érdeklődésre tarthat számot - gondoljunk csak az Atlas Florae Europaeae sorozat munkálataira!

$\mathrm{Az}$ atlasz térképein alapuló következtetések azonban csak akkor lehetnek helyesek, ha maguk a térképek is megközelítőleg pontosan tükrözik az egyes taxonok elterjedését illetve gyakoriságát. Térképeink azonban több oknál fogva sem lehetnek tökéletesek. Egyrészt, míg a térképek statikusak, a flóra koránt sem az: egyes fajok terjednek, mások visszaszorulnak. Ezek a tendenciák az archív adatok csekély feldolgozottsága miatt a jelenlegi térképeken nem, vagy csak bizonyos esetekben rajzolódnak ki. Másrészt, változik az egyes csoportok taxonómiai megítélése. Ezt az atlasz taxonómiai-nevezéktani alapjának tekinthető Új magyar füvészkönyv (KIRÁLY 2009) tükrözi is (összevetve a korábbi határozó generációkkal), ám a kritikus taxonok flóratérképezési adatai sok esetben bizonytalanok, pontatlanok, így sokukról összevont (agg., s. l.) térképek jelentek meg. Harmadrészt, a térképezés módszertanából (KIRÁLY et al. 2003) adódóan bizonyos csoportok esetében alulreprezentáltság sejthető (például ritka fajok, a kora tavaszi aszpektus tagjai, évjárathatástól erősen függő megjelenésű efemerek, urbán területekhez kötődő fajok stb.).

Ezek alapján az elkövetkező évek fontos feladata lesz a Flóraatlasz térképeinek kiegészítése i) archív irodalmi és herbáriumi adatok feldolgozásával, ii) a kritikus taxonok elterjedésének és gyakoriságának tisztázásával, iii) a publikálatlan adatok közlésével és további aktuális előfordulási adatok gyűjtésével. A cikksorozatot az utóbbi két célkitűzéssel indítjuk útjára.

\section{Anyag és módszer}

A közleményben a szerzők az utóbbi években (2004 és 2016 között) gyűjtött előfordulási adatok közül válogatták össze azokat, amelyek Magyarország edényes növényfajainak elterjedési atlasza térképein nem szerepelnek, esetleg az ott megadottól eltérő státuszú az adat. Az adatok jelentős része a Magyarország veszélyeztetett hajtásos növényeinek ritkasága, életmenet-jellemzői és klímaválasza című OTKA pályázat (témavezető: Molnár V. Attila) terepmunkái (például veszélyeztetett és ritka fajok autökológiai adatainak gyűjtése, hazai temetők védett fajainak felmérése, faültetvények orchidea-flórájának vizsgálata) közben került elő.

Közleményünk két szempontból is eltér a megszokott florisztikai cikkektől. Egyrészt, az Enumerációba olyan országosan gyakori taxonokat is fölvettünk, amelyek esetében az atlasz térképei adathiányt mutatnak. Erre jó példa a salátaboglárka (Ranunculus ficaria), amely KIRÁLY (2009) szerint „Magyarország egész területén gyakori”, ehhez képest BARTHA et al. (2015) térképe alapján az Alföldön szórványosnak, sőt, a Duna-Tisza-közén kifejezetten ritkának mutatkozik. Bár élőhelyei kétségkívül kisebb kiterjedésűek az utóbb említett térségben, jelenlétét mégis alulreprezentáltnak tartjuk BARTHA et al. (2015) térképén. Másrészt, országos léptékű (összesen 247 negyedkvadrátra; 1. ábra), nagyszámú (összesen 297) taxonra kiterjedő adatgyűjtésről és adatközlésről lévén szó, ezúttal nem vállalkozhattunk herbáriumi és irodalmi referenciák részletes feldolgozására. Nem áll 
szándékunkban ezek jelentőségének csorbítása, sőt, kiemelten fontosnak tartjuk az ezekben rejlő adatok feltárását és feltüntetését a térképeken. A releváns adattömeg áttekintése azonban meghaladja egy, a jelenlegihez hasonló közlemény ésszerű lehetőségeit. Ebből következően - bár igyekeztünk kerülni - előfordulhat redundáns adatközlés. Másként fogalmazva: nem állíthatjuk, hogy minden itt közölt előfordulás új az adott területre nézve, csupán annyit, hogy BARTHA et al. (2015) térképe kiegészítendő az adattal. E vitatható megoldás mentségére szól, hogy a Flóraatlasz szerkesztése során a KEF-kódok hiánya miatt fel nem dolgozott irodalmi források többsége archív anyag, így adataik egyébként is aktuális megerősítésre szorulnak.

Az alább közölt adatok jelentős részéről herbáriumi dokumentáció készült. A példányok a Debreceni Egyetem gyűjteményében (DE) kerültek elhelyezésre.

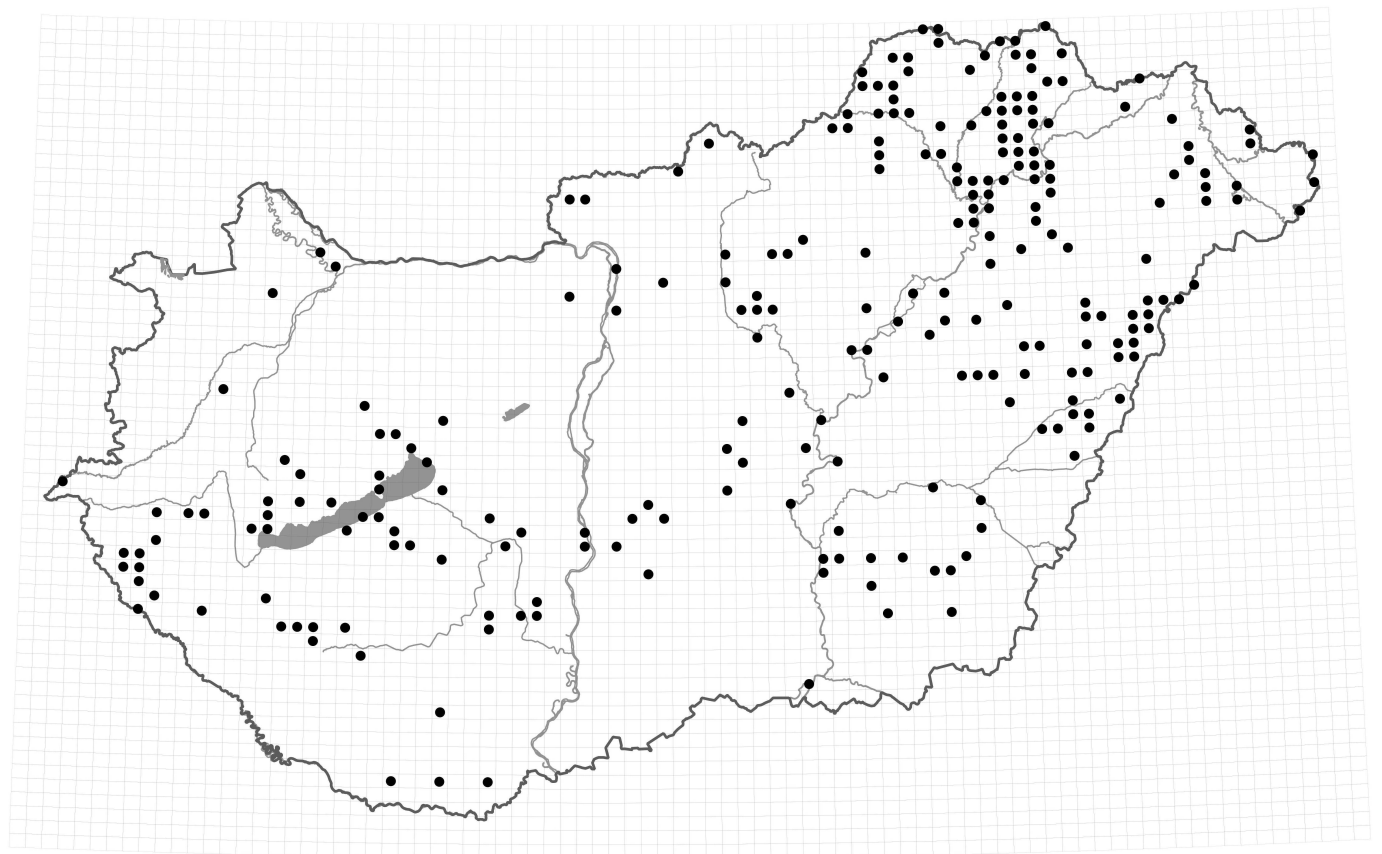

1. ábra. A közleményben összefoglalt előfordulási adatok a közép-európai flóratérképezés (KEF) hálórendszerének negyedkvadrátjaira vetítve Fig. 1. Distribution of localities of presented data, in projection of quarter quadrates of the Central Europaean flora mapping system (CEU)

\section{Enumeráció}

3. Diphasium complanatum (L.) Rothm. - Miskolc: Létrás-tető és Jávorkút között, turistaút mellett [7989.1, TA].

5. Lycopodium clavatum L. - Háromhuta-Újhuta: falu szélén a Flórika-forrás felé [7694.2, TA].

6. Lycopodium annotinum L. - Telkibánya: Hercegfia-bérc [7594.1, MVA, TA, LKÁ].

12. Equisetum fluviatile L. em. Ehrh. - Tiszalúc: Takta ártér, kubikgödörben [7992.3, TA].

13. Equisetum palustre L. - Bagamér: Kék-kálló-völgye [8497.4, LBA]; Penészlek: Peces-tó [8399.3, LBA].

26. Polypodium vulgare L. - Tokaj, Tarcal: Felhagyott kőbányák falain sokfelé [7894.3, TA].

31.Phegopteris connectilis (Michx.) Watt - Telkibánya: Hercegfia-bérc és Borinzás [7594.1, MVA, TA, LKÁ]. 
37.Asplenium trichomanes L. - Keszthely: Kossuth Lajos u., kőfalakon [9269.1, NT, TA]; Tokaj, Tarcal: a Tokaji-hegy völgyeiben, felhagyott bányáiban sokfelé [7894.3, TA].

40. Asplenium ruta-muraria L. - Keszthely: Kossuth Lajos u., kőfalakon [9269.1, NT, TA]; Tokaj: Táncsics u., kőfalon [7894.3, TA].

42.Athyrium filix-femina (L.) Roth - Tokaj, Tarcal: a Tokaji-hegy É-i lejtőin és völgyekben sokfelé [7894.3, TA].

46.Gymnocarpium dryopteris (L.) Newman - Telkibánya: erdei utak mentén többfelé [7594.1, TA].

51.Polystichum aculeatum (L.) Roth - Tokaj: Lencsés-völgy [7894.3, TA]; Vajszló: Luzsok felé, telepített nyarasban [0173.2, MVA, NT, TA].

55.Dryopteris filix-mas (L.) Sch. - Mezőpeterd: Kréta, telepített nyarasban [8895.2, LKÁ, MVA, SG, TA]; Tokaj, Tarcal: a Tokaji-hegy É-i lejtőin és völgyekben sokfelé [7894.3, TA].

56.Dryopteris carthusiana (Vill.) H.P. Fuchs - Tokaj, Tarcal: a Tokaji-hegy É-i lejtőin [7894.3, TA].

89.Juniperus communis L. - Tarcal: a Kiskopasz fölött, a csúcstól Tarcal felé haladó vezetékek alatt [7894.3, TA].

98. Salix rosmarinifolia L. - Nyírábrány: Teleki-legelő [8498.1, PWP].

146. Urtica urens L. - Keszthely: Kossuth Lajos u., járdaszegélyen [9269.1, NT, TA]; Nyírábrány: Teleki-legelő [8498.1, PWP].

153. Thesium linophyllon L. - Kereki: temető melletti gyepben [9173.3, NT, TA].

156. Viscum album L. subsp. album - Kereki: temető [9173.3, NT, TA]; Ófehértó: Korhányierdő [8098.3, NT, TA]; Pusztaszemes: temető [9273.2, NT, TA].

158. Aristolochia clematitis L. - Nyírábrány: Keszler-tag [8498.1, PWP].

160. Persicaria bistorta (L.) Samp. - Nyirád: Sárálló [8970.3, 9070.2, MVA, TA].

197. Rumex confertus Willd. - Abaújszántó: Gyűr-völgy [7793.1, NT, TA]; Baskó: Hallgatóoldal [7693.4, NT, TA]; Erdőbénye: Nagy-rétek [7794.1, NT, TA].

198. Rumex conglomeratus Murray - Tiszaújváros: Maloggyás [8092.4, MVA, TA, LKÁ].

220. Chenopodium vulvaria L. - Csorna: Mártírok tere, padkarepedésben [8369.4, LKÁ, LV, SK]; Debrecen: Gyergyó utca [8495.4, SK].

226. Chenopodium opulifolium Schrad. - Gyöngyös: Karácsondi út, a falatozónál [8285.2, $\mathrm{TA}]$.

254. Salsola soda L. - Dunatetétlen: Dög-szék [9280.4, TA].

255. Salsola kali L. - Homokkomárom: homokbánya [9567.2, MVA].

265. Amaranthus deflexus L. - Hevesvezekény: a temető kerítése mentén [8488.1, TA]; Keszthely: vasútállomás [9269.1, NT, TA]; Pusztamonostor: belterület (Szabadság út) és temető [8484.2, TA]; Tiszabura: belterület (Kossuth utca) [8588.4, TA].

267. Amaranthus crispus (Lesp. et Thévenau) N. Terracc. - Tetétlen: temető [8693.4, TA].

269. Amaranthus albus L. - Hidasnémeti: vasútállomás [7493.3, TA]; Jászdózsa: Jászárokszállás felé, telepített tölgyes melletti árokban [8485.2, TA]; Lakitelek: Tiszaughídfő [9186.1, TA].

300. Cerastium dubium (Bastard) Guépin - Hajdúvid: Fekete-dűlő [8295.1, NT, TA]; Mezőzombor: Sár-rét [7893.4, NT, TA]; Polgár: az M3 autópálya felhajtójánál [8192.4, SK]; Tiszavasvári: Fehér-szik [8094.2, NT, TA].

301. Cerastium glomeratum Thuill. - Fülpösdaróc: temető [8000.4, NT, TA]; Győrtelek: temető [8000.4, NT, TA]; Hőgyész: a Malom-hegy K-i lábánál, út mentén [9576.2, NT, TA]; Miklósgerge: temető [7883.2, LV, NT, TA]; Nagydobos: a Károlyi-erdőtôl ÉNy-ra fekvő gyepben [7999.4, NT, TA]; Ópályi: ótemető (Árpád u.) [8099.2, NT, TA].

303. Cerastium brachypetalum Desp. - Szentes: Tisza menti töltés [9387.1, NT, TA].

305. Cerastium semidecandrum L. - Boldogkőváralja: Vár-hegy [7693.3, NT, TA]; Újszász: vasútállomás [8786.1, NT, TA].

313. Moenchia mantica (L.) Bartl. - Hetes: halastó mellett [9572.3, NT]. 
330. Spergula pentandra L. - Gemzse: izraelita temető [7899.3, NT, TA]; Ópályi: ótemető (Rajk László u.) [7999.4, 8099.2, NT, TA].

349. Silene multiflora (Waldst. et Kit.) Pers. - Fülöp: Százholdas [8498.2, MVA, TA].

370. Dianthus deltoides L. - Zalaszántó: a Nagy-réti-patak és a Büdös-kúti-dűlő közötti réten [9169.2, MVA, TA].

394. Isopyrum thalictroides L. - Hetes: halastó melletti tölgyesben [9572.3, NT].

408. Anemone ranunculoides L. - Magosliget: Fischer-erdő [7903.1, MVA]; Miskolc: Avasi református temető [7890.4, SK].

411. Anemone nemorosa L. - Márokpapi-Tarpa: Téb-erdő [7801.3, MVA].

417. Pulsatilla zimmermannii Soó - Szentistvánbaksa: Bika-rét [7792.3, KJ, TA].

418. Tephroseris integrifolia (L.) Holub - Szentistvánbaksa: Baksa-halom és Bika-rét [7792.3, KJ].

423. Clematis recta L. - Szuhakálló: Szuha menti töltésen a Kazincbarcika felé tartó műút hídjánál [7790.1, TA]; Újléta: Új-Ócsa [8597.3, FR].

424. Adonis vernalis L. - Enying-Balatonbozsok: Kétcsapás-közi-dűlő [9075.3, NT, TA].

427. Adonis aestivalis L. - Kánya: Tab felé, repceföld szélén [9274.3, NT, TA].

434. Ranunculus trichophyllus Chaix - Hajdúvid: Fekete-dűlő [8295.1, NT, TA].

435. Ranunculus ficaria L. - Csorvás: Micsurin utcai temető [9391.3, TA, NT, MVA]; Csorvás: Batthyány utcai temető [9390.4, TA, NT, MVA]; Egyek-Félhalom: a falurész melletti telepített nyarasban [8391.3, NT, NK, MVA, TA, SK]; Fábiánsebestyén: temető [9388.2, TA, NT, MVA]; Furta: Berettyóúffalu felé, út mentén [8894.4, TA, NT, MVA]; Furta: temető [8894.4, TA, NT, MVA]; Gyomaendrőd: Körös menti töltésen [9090.4, NK]; Hetes: az iskola melletti parkban [9572.3, TA, NT]; Murony: temető [9292.1, TA, NT, MVA]; Nagyszénás: temető [9389.2, TA, NT, MVA]; Nemesbikk: a Szúnyog-domb alatt [8191.2, MVA, TA].

437. Ranunculus illyricus L. - Enying-Balatonbozsok: Kétcsapás-közi-dűlő [9075.3, NT, TA]; Tarcal: Kiskopasz [7894.3, NT, TA]; Debrecen: Klinikák (Auguszta) [8495.2, LKÁ]; Ófehértó: Korhányi-erdő, a Baktalórántházára tartó múút mentén [8098.3, NT, TA].

440. Ranunculus polyphyllus Waldst. et Kit. - Kesznyéten: Majorsági-dúlő [8092.1, NT, TA].

442. Ranunculus flammula L. - Szemere: Rakaca-patak forrásvidéke [7592.2, TA]; Telkibánya: Ósva-völgy [7594.1, TA].

445. Ranunculus bulbosus L. - Maróc: belterületen [9465.2, NT, TA, FR, MVA].

448. Ranunculus arvensis L. - Újszentmargita: ótemető [8292.4, MVA, TA].

451. Ranunculus polyanthemos L. - Tószeg: temető [8986.2, NT, TA].

459. Myosurus minimus L. - Hajdúvid: Fekete-dűlő [8295.1, NT, TA]; Hárskút: Égett-hegy északi lábánál, földúton [8772.4, MÁ]; Márokpapi: a Navat-tótól ÉK-re, bolygatott gyepben [7801.1, NT, TA].

462. Thalictrum minus L. - Sárrétudvari: temető [8793.3, MVA, SK, TA].

471. Mahonia aquifolium (Pursh) Nutt. - Nagybajom: a falutól É-ra, a Lencsen-puszta közelében [9571.3, NT, TA]; Sitke: Újhegy [8768.1, NT, TA].

485. Corydalis cava L. - Magosliget: Fischer-erdő [7903.1, EVA, LV, MVA, NT, SK].

488. Corydalis solida L. - Abaújszántó: Aranyos-völgy [7793.1, MVA, TA, NT]; Felsőgagy: temető [7592.3, MVA, NT, TA]; Hernádbüd: temető [7792.2, MVA, NT, TA]; Lispeszentadorján: Lispei-erdő [9466.3, MVA]; Miskolc: Avasi református temető [7890.4, SK].

497. Sisymbrium altissimum L. - Abaújszántó: Gyűr-tető [7793.1, NT, TA].

506. Bunias orientalis L. - Hőgyész: a Malom-hegy K-i lábánál, út mentén [9576.2, NT, TA]; Iregszemcse: Tamási irányába, a falu szélén [9375.1, NT, TA]; Karcag: Apavára, vasúti sínek mentén [8692.3, NT, TA]; Nagydobos: a Károlyi-erdőhöz vezető földút hídjánál és a Kraszna menti töltésen [7999.4, NT, TA]; Tihany: az Apáti-tető É-i lábánál [9073.3, TA]; Tunyogmatolcs: belterületen és a Győrtelekre vezető út mentén [8000.2, NT, TA]. 
510. Erysimum diffusum Ehrh. - Balatonfüred: Tamás-hegy [9073.1, MVA, TA]; Balatonkenese: Soós-hegy [8974.4, MVA, TA].

516. Hesperis tristis L. - Szendrő: Várdomb, temető [7590.3, LV, MVA, TA]; Tarcal: Teréziakápolna [7894.3, TA].

518. Hesperis sylvestris Crantz - Felsőnyárád: a falutól K-re, bányagödör feletti sztyeplejtőn [7689.4, TA].

525. Barbarea stricta Andrz. - Győrújfalu: a Duna bal partján, a Szúnyog-szigetnél [8271.4, MVA, TA]; Sződliget: a Sződrákosi-patak torkolatánál [8280.4, MVA, TA]; Tiszafüred: Tisza ártér [8390.3, MVA, TA].

531. Armoracia macrocarpa (Waldst. et Kit.) Kit. ex Baumg. - Mezőzombor: Sár-rét [7893.4, NT, TA]; Prügy: Úrrét [7893.3, NT, TA].

537. Cardamine bulbifera (L.) Crantz - Nyírábrány: Kis-Mogyorós erdő [8498.1, PWP].

538. Cardamine parviflora L. - Kesznyéten: Majorsági-dúlő [8092.1, NT, TA].

539. Cardamine hirsuta L. - Böhönye: Fő utca, a Diófa vendéglő előtt [9570.3, NT, TA]; Fábiánsebestyén: temető [9388.2, TA, NT, MVA]; Gyenesdiás: a Berzsenyi-kilátó közelében [9269.2, NT, TA]; Mikepércs: Bocskai utca [8595.4, SG]; Szentes: belterület, a szülészet körüli parkban [9387.2, TA].

549. Arabis recta Vill. - Fülöpszállás: temető [9181.3, NT, TA]; Hídvégardó: Szent János-kő [7491.3, TA, NT, MVA].

569. Draba nemorosa L. - Prügy: ótemető [7993.2, NT, TA].

570. Draba muralis L. - Zselicszentpál: temető [9672.4, MVA, NT, FR, TA].

574. Camelina microcarpa Andrz. ex DC. - Polgár: az M3 autópálya felhajtójánál [8192.4, SK].

583. Thlaspi perfoliatum L. - Bagamér: Daru-hegyek [8597.2, PWP]; Berettyószentmárton: temető [8895.1, 8795.3, TA, NT, MVA]; Fábiánsebestyén: temető [9388.2, TA, NT, MVA]; Furta: temető [8894.4, TA, NT, MVA]; Nagymágocs: temető [9488.2, TA, NT, MVA]; Székkutas: temető [9589.1, TA, NT, MVA]; Telekgerendás: a falu É-i szélén, út mentén [9391.2, TA, NT, MVA].

608. Diplotaxis tenuifolia (L.) DC. - Debrecen: Károli Gáspár utca [8495.2, LV, TA]; Debrecen: Újkert, Jerikó utca [8495.4, LV, TA]; Keszthely: Büdöskúti út [9169.4, TA]; Szendrő: Várdomb, temető [7590.3, NT, TA].

620. Erucastrum nasturtiifolium (Poir.) O.E. Schulz - Litér: Mogyorós-hegy [8974.1, MVA, TA]; Sződliget: Duna menti töltésen [8280.4, LBA, MVA, TA].

622. Calepina irregularis (Asso) Thell. - Gyomaendrőd: Körös menti töltésen [9090.4, NK]; Szeged: Tisza menti töltés [9786.4, SK]; Szentes: Tisza menti töltés [9387.1, TA]; Tarcal: a Tokaji-hegy lábánál, szőlők között [7894.3, TA]; Veszprém: vasútállomás [8873.3, TA].

643. Sedum acre L. - Nyírmihálydi: temető [8297.4, NT, TA].

647. Saxifraga tridactylites L. - Abaújszántó: Gyür-tető [7793.1, NT, TA]; Erdőbénye: Mulató-hegy [7794.1, TA, NT, MVA]; Hídvégardó: Szent János-kő [7491.3, TA, NT, MVA]; Jászberény: vasútállomás [8585.1, NT, TA]; Martfú: vasútállomás [8987.4, NT, TA]; Nagybajom: a faluközpontban, virágágyásban [9671.1, NT, TA]; Nagytőke: vasúti megállóhely [9287.2, NT, TA]; Nyírábrány: Teleki-legelő [8498.1, PWP]; Tiszalúc: vasútállomás [7992.3, NT, TA].

685. Rosa gallica L. - Berettyóújfalu: Tardi-szik [8795.3, LKÁ, MVA, SG, TA]; Tállya: Patócshegy [7793.3, TA];

711. Sanguisorba officinalis L. - Bagamér: Kék-kálló-völgye [8497.4, LBA]; Nyírábrány: Keszler-tag [8498.1, MVA]; Újléta: Nagy-Ócsa [8597.3, FR].

717. Potentilla indica (Andrews) Focke - Hajdúszoboszló: Csepüs sori temető gyepjében [8594.3, TA]; Kecskemét: református temető (Budai út) [9084.3, NT, TA]; Tiszaszentimre: Pusztakettős, kultúrgyepben [8590.2, TA]. 
719. Potentilla rupestris L. - Dobronhegy: Kandikó [9166.3, MVA, TA]; Szakonyfalu: temető melletti útbevágás [9063.3, LV, MVA].

723. Potentilla supina L. - Bőcs: Bányató [7991.4, TA]; Konyár: Bodzás [8695.4, MVA, LKÁ, $\mathrm{SG}]$.

724. Potentilla erecta (L.) Rausch - Nyírábrány: Keszler-tag [8498.1, MVA]; Zalaszántó: a Nagy-réti-patak és a Büdös-kúti-dűlő közötti réten [9169.2, MVA, TA].

730. Potentilla recta L. - Köröstarcsa: temető [9192.1, TA, NT, MVA].

731. Potentilla heptaphylla L. - Baskó: Kőrös-hegy [7694.3, NT, TA]; Boldogkőújfalu: temető [7693.3, NT, TA]; Kapoly: a Bőcse É-i lejtőin [9273.4, NT, TA]; Kereki: temető [9173.3, NT, TA]; Mályinka: temető [7889.1, TA, NT, MVA]; Nekézseny: temető [7888.2, TA, NT, MVA]; Pusztaszemes: temető [9273.2, NT, TA]; Sajómercse: temető [7788.3, TA, NT, MVA]; Tevel: temető [9576.4, NT, TA].

732. Potentilla patula Waldst. et Kit. - Abasár: temető [8286.1, LV, NT, TA]; Tállya: Patócshegy [7793.3, NT, TA].

814. Crataegus laevigata (Poir.) DC. - Hídvégardó: Kecske-vár [7491.1, LBA, EVA, SK].

819. Cerasus mahaleb (L.) Mill. - Tarcal: bányató mellett [7894.3, PWP].

844. Chamaecytisus ratisbonensis (Schaeff.) Rothm. - Erdőbénye: Mulató-hegy [7794.1, TA].

848. Genista germanica L. - Hernyék: Zsohár-fenyős [9365.2, MVA, TA].

869. Astragalus glycyphyllos L. - Tiszaderzs: Cserőközi Holt-Tisza [8489.4, MVA, TA, SG].

900. Vicia lathyroides L. - Debrecen: Fancsikai-tavak környékén [8496.3, NT, TA]; Gemzse: izraelita temető és köztemető [7899.3, NT, TA]; Nyírmihálydi: temető [8297.4, NT, TA]; Ópályi: ótemető (Árpád u.) [8099.2, NT, TA]; Tiszavasvári: belterület, az Alkaloida előtti iparvágányok között [8094.3, NT, TA].

901.1. Vicia pannonica Crantz - Kánya: Tab felé, repceföld szélén [9274.3, NT, TA]; Kereki: temető melletti gyepben [9173.3, NT, TA]; Tállya: Patócs-hegy [7793.3, TA].

901.2. Vicia pannonica Crantz subsp. striata (M. Bieb.) Nyman - Apc: temető [8284.1, LV, NT, TA]; Domoszló: temető [8186.4, LV, NT, TA]; Tiszaderzs: temető [8489.4, MVA, TA]; Tószeg: temető [8986.2, NT, TA]; Vácegres: Partok alja, földutak mentén [8382.1, LBA, MVA, TA];

911. Lathyrus nissolia L. - Hortobágy: Szálkahalom [8493.1, MVA].

926. Lathyrus lacteus (M. Bieb.) Wissjul. - Tarcal: Kiskopasz [7894.3, TA].

953. Medicago minima (L.) L. - Tállya: Patócs-hegy [7793.3, TA].

962. Trifolium dubium Sibth. - Debrecen: Klinikák (Auguszta) [8495.2, LKÁ].

1013. Geranium Iucidum L. - Cece: temető [9277.2, NT, TA].

1025. Erodium ciconium (Jusl.) L'Hér. - Balatonkenese: Soós-hegy [8974.4, MVA, TA].

1026. Tribulus terrestris L. - Balatonszárszó: vasútállomás, peron repedései között [9172.4, NT]; Debrecen: Füredi út, járda mentén a Kisgömböc Ételbár előtt [8495.4, TA]; Hidasnémeti: vasútállomás [7493.3, TA].

1027. Linum catharticum L. - Cegléd: Csíkos-szél [8884.2, MVA, TA]; Nagykapornak: a Nagydombi-dűlő és a Pusztika között [9167.4, MVA]; Zalaegerszeg-Csácsbozsok: homokbánya [9167.3, MVA].

1034. Linum austriacum L. - Dunatetétlen: Dög-szék [9280.4, MVA, TA]; EnyingBalatonbozsok: Kétcsapás-közi-dűlő [9075.3, NT, TA].

1038. Mercurialis perennis L. - Abaújszántó: Aranyos-völgy [7793.1, MVA, TA, NT].

1042. Euphorbia maculata L. - Budapest: IV. kerület, Megyeri út és Attila utca [8480.2, LKÁ, MVA]; Füzesabony: vasútállomás, 3. vágány, a peron repedéseiben [8288.2, TA]; Hidasnémeti: vasútállomás [7493.3, TA]; Lakitelek: Lakitelek [9186.1, MVA]; Zalaegerszeg: a Penny Market parkolójában [9167.3, MVA, NT, TA].

1052. Euphorbia epithymoides L. - Pécs: Lapis [9875.3, MVA, TA].

1058. Euphorbia salicifolia Host - Erdőbénye: Mulató-hegy [7794.1, TA]. 
1070. Dictamnus albus L. - Sajógalgóc: Nagy-Pallag tatárjuharos-mezei juharos-molyhos tölgyes bokorerdejében és sziklakibúvás szélén [7789.1, MÁ].

1100. Rhamnus catharticus L. - Tiszavasvári: a Fehér-szik déli partjánál [8094.2, NT, TA].

1135. Thymelaea passerina (L.) Coss. et Germ. - Tarcal: Kiskopasz [7894.3, TA]; Tornanádaska: Nagyoldal [7490.2, EVA, SK].

1150. Viola tricolor L. - Gönyű: Gönyűi-erdo, földutak mentén [8272.4, MVA, TA].

1152. Viola kitaibeliana Roem. et Schult. - Abaújszántó: Sátor-hegy [7793.1, TA, NT, MVA]; Boldogkőváralja: Vár-hegy [7693.3, NT, TA]; Kánya: Tab felé, repceföld szélén [9274.3, NT, TA]; Kereki: temető [9173.3, NT, TA]; Szerencs-Ond: temető [7893.1, TA, NT, MVA]; Tiszavasvári: belterület, az Alkaloida előtti iparvágányok között [8094.3, NT, TA]; Újszász: vasútállomás [8786.1, NT, TA].

1153. Viola alba Besser - Gyenesdiás: a Berzsenyi-kilátó közelében [9269.2, NT, TA].

1159. Viola ambigua Waldst. et Kit. - Abaújszántó: Sátor-hegy és Gyűr-tető [7793.1, TA, NT, MVA].

1162. Viola riviniana Rchb. - Lispeszentadorján: Lispei-erdő [9466.3, MVA, NT, FR, TA]; Nagybajom: Böhönye felé, a 61-es út menti erdőkben [9570.4, MVA, NT, FR, TA]; Rudabánya: temető [7689.2, LV, MVA, TA]; Somogyzsitfa: Szőcsenypuszta körüli erdőkben [9469.4, MVA, NT, FR, TA].

1164. Viola canina L. - Garbolc: Hármashatár [8003.1, TA].

1175. Elatine alsinastrum L. - Berettyóújfalu: Vancsodi-dűlő [8895.4, MVA]; Kesznyéten: Majorsági-dűlő [8092.1, NT, TA]; Prügy: Úrrét [7893.3, NT, TA].

1194. Peplis portula L. - Konyár: Bodzás [8695.4, MVA, LKÁ, SG]; Tiszaderzs: Sulymos [8489.4, MVA, TA, SG].

1217. Chamaenerion angustifolium (L.) Scop. - Szentes: Mikec-dűlo, Kurca-part [9387.3, MVA, NT, TA].

1244. Eryngium planum L. - Baskó: temető [7694.3, TA]; Szendrő: Korlát-hegy, földúton [7590.3, TA].

1271. Seseli varium Trevir. - Abaújszántó: Gyűr-tető [7793.1, NT, TA]; Prügy: ótemető [7993.2, NT, TA].

1304. Angelica sylvestris L. - Létavértes: Falu-rét [8697.1, FR].

1311. Peucedanum officinale L. - Berettyóújfalu: Tardi-szik [8795.3, LKÁ, MVA, SG, TA].

1312. Peucedanum alsaticum L. - Dunatetétlen: Böddi, műút mentén [9280.4, MVA, TA].

1315. Peucedanum oreoselinum (L.) Moench - Debrecen: a Fancsikai-tavaktól a 48-as útra vezető műút vasúti átjárójánál [8496.3, NT, TA].

1324. Torilis arvensis (Huds.) Link - Hárskút: Rák tanya [8772.4, MÁ].

1329. Orlaya grandiflora (L.) Hoffm. - Gyenesdiás: Ló-hegy [9269.2, NT, TA].

1347. Primula vulgaris Huds. - Hetes: az iskola melletti parkban [9572.3, TA, NT].

1351. Androsace elongata L. - Abaújszántó: Sátor-hegy [7793.1, TA, NT, MVA]; Alsóvadász: temető [7791.3, LV, MVA, TA]; Baskó: Hallgató-oldal [7693.4, NT, TA]; Gyomaendrőd: Körös menti töltésen [9090.4, NK]; Hatvan: vasútállomás [8384.1, NT, TA]; Miskolc: Szentpéteri kapui köztemető [7890.4, LV, MVA, TA]; Nagytőke: vasúti megállóhely [9287.2, NT, TA]; Szerencs-Ond: temető [7893.1, TA, NT, MVA]; Újszász: vasútállomás [8786.1, NT, TA].

1363. Samolus valerandi L. - Cegléd: Csíkos-szél [8884.2, MVA, TA].

1382. Centaurium pulchellum (Sw.) Druce - Tiszaroff: Szilvási-dűloút [8588.3, TA].

1383. Centaurium erythraea Raf. - Berettyóújfalu: Tardi-szik [8795.3, SG, TA, MVA]; Nemesbikk: a Szúnyog-domb alatt [8191.2, MVA, TA].

1391. Nymphoides peltata (S.G. Gmel.) Kuntze - Muraszemenye: bánya [9565.2, MVA, FR, LV].

1396. Vincetoxicum hirundinaria Medik. - Karcag: északi temető [8691.4, LV, MVA]. 
1407. Cuscuta epithymum (L.) Nath. - Berettyóújfalu: Tardi-szik [8795.3, SG, TA, MVA]; Kesznyéten: Szamár-hát [8092.1, TA]; Tiszalúc: Himes-tó-hát [7992.3, TA]; Tiszalúc: Horgoló-puszta [7992.4, TA]; Tiszaújváros: Inér-háti kaszálók [8092.2, 8092.4, TA].

1414. Buglossoides arvensis (L.) I.M. Johnston - Bőcs: Sajólád felé, műút mezsgyéjén [7991.4, TA]; Kisvárda: Akácfa utcai temető [7798.4, NT, TA]; Szolnok: Szandai-nagy-rét [8887.1, MVA, TA]; Vámospércs: ótemető [8497.3, NT, TA].

1418. Cerinthe minor L. - Újléta: Kapott-tag [8597.1, FR].

1426. Pulmonaria mollissima A. Kern. - Csengersima: Géci-sűrü [8102.2, TA]; Nova: a Makkosi-hegy és a Felső-hegy É-i lábánál [9266.3, MVA, TA]; Tokaj: a Tokaji-hegy É-i lejtői [7894.3, TA].

1428. Nonea pulla DC. - Nyírábrány: Teleki-legelő [8498.1, PWP].

1440. Asperugo procumbens - Mezőzombor: a temető peremén [7893.4, NT, TA]; Nagykőrös: katolikus temető [8984.4, NT, TA]; Szeged: vasútállomás [9786.4, SK]; Szerencs: temető [7893.1, TA, NT, MVA].

1447. Myosotis stricta Link - Nyírábrány: Teleki-legelő [8498.1, PWP].

1455. Lappula squarrosa (Retz.) Dumort. - Tokaj: a Dessewffy löszmélyút löszfalain [7894.3, TA].

1470. Ajuga chamaepitys (L.) Schreb. - Mezőszilas: temető (Petőfi u.) [9176.4, NT, TA].

1473. Ajuga genevensis L. - Lenti: Mumor felé, erdei út mentén [9365.3, MVA, TA]; Sajóhídvég: temető [7991.4, MVA, TA].

1478. Teucrium scordium L. - Hortobágy: Szásztelek [8492.3, SG, TA].

1480. Scutellaria galericulata L. - Füzér: Drahos [7494.2, TA].

1488. Phlomis tuberosa L. - Hortobágy: Kaparócsárda [8491.3, MVA, NK, TA].

1542. Lycopus exaltatus L. f. - Vámospércs: víztározó [8497.4, PWP].

1557. Salvia glutinosa L. - Bázakerettye-Kistolmács: a Borsfára vezető út mentén [9466.3, MVA].

1560. Salvia austriaca Jacq. - Bőcs: belsőbőcsi temető [7991.4, MVA, TA]; Tiszavasvári: a Fehér-szik déli partjánál [8094.2, NT, TA].

1571. Hyoscyamus niger L. - Hajdúböszörmény: Ráskai dűlő [8293.2, MVA, TA].

1577. Solanum dulcamara L. - Regéc: Hosszú-kő [7594.3, TA].

1590. Gratiola officinalis L. - Konyár: Bodzás [8695.4, MVA, LKÁ, SG]; Szolnok: Szandainagy-rét [8887.1, MVA, TA].

1591. Lindernia procumbens (Krock.) Philcox - Konyár: Bodzás [8695.4, MVA, LKÁ, SG]; Tiszaderzs: Sulymos [8489.4, MVA, TA, SG]; Tiszagyenda: Libasor [8689.3, LBA, MVA].

1593. Limosella aquatica L. - Tiszaderzs: Sulymos [8489.4, MVA, TA, SG]; Tiszagyenda: Libasor [8689.3, LBA, MVA].

1612. Microrrhinum minus (L.) Fourr. - Debrecen: Dóczy József u., Teniszke (Objektum) grillbüfé teraszán, virágágyásban [8495.2, TA]; Debrecen: Sinai Miklós utca [8495.4, SK]; Gyenesdiás: Malom u., malom melletti ösvény szélén [9269.2, NT, TA]; Keszthely: Büdöskúti út [9169.4, TA].

1614. Linaria genistifolia (L.) Mill. - Tiszavasvári: a Fehér-szik déli partjánál kialakított parkolóban [8094.2, NT, TA].

1615. Linaria angustissima (Loisel.) Borbás - Bekecs: Közép-hegy [7893.1, TA].

1617. Linaria biebersteinii Besser - Debrecen: Auchan parkoló [8495.4, MVA, TA]; Kaszaper: Doktor-dűlő - Montághy-úti-föld, műút mezsgyéjén [9591.3, MVA, SG].

1618. Cymbalaria muralis G. Gaertn., B. Mey. et Scherb. - Debrecen: Egyetem tér: a Botanikus Kertben és a Kémia Épület egyik szellőző aknájában [8495.2, SK]; Debrecen: Sas utca, falak mentén, illetve Bethlen utca 43-44., a háztömb tövében [8495.4, TA]; Keszthely: Széchenyi u., kőfalon [9269.1, NT, TA]; Miskolc: Szinva terasz [7890.4, SK] és Erzsébet-tér [PWP]; Tevel: temető [9576.4, NT, TA]; Tokaj: belterület, Óvár utca [7894.3, TA]. 
1619. Kickxia spuria (L.) Dumort. - Perkupa: Somos-láb [7589.2, NT, TA]; Zádorfalva: Szuha-völgy [7688.2, NT, TA].

1625. Pseudolysimachion longifolium (L.) Opiz - Bagamér: Kék-kálló-völgye [8497.4, LBA]; Szalonna: Perkupa felé, a Bódva mentén [7590.1, FR]; Szentes: Tisza menti töltés [9387.1, NT, TA]; Szuhafő: a Korlát-patak mentén [7588.4, NT, TA].

1628. Pseudolysimachion spicatum (L.) Opiz - Hajdúszoboszló: Kéthalom [8593.4, MVA, SK, TA].

1638. Veronica austriaca L. - Tarcal: Kiskopasz alsó része [7894.3, TA].

1644. Veronica triphyllos L. - Abaújszántó: Sátor-hegy, szőlők között [7793.1, TA, NT, MVA]; Debrecen: a Fancsikai-tavaktól a 48-as útra vezető műút vasúti átjárójánál [8496.3, NT, TA]; Ilk: ótemető [7899.3, NT, TA]; Nagykőrös: katolikus temető [8984.4, NT, TA]; Nyírmada: ótemető [7999.1, NT, TA]; Nyírmeggyes: ótemető [8099.4, NT, TA]; Ópályi: ótemető (Rajk László u.) [7999.4, 8099.2, NT, TA]; Rohod: temető [7998.4, NT, TA]; Tengelic: temető [9478.3, NT, TA]; Tiszatardos: komp fölötti töltésen [7994.3, NT, TA]; Tiszavasvári: belterület, az Alkaloida előtti iparvágányok között [8094.3, NT, TA]; Vámospércs: ótemető [8497.3, NT, TA].

1645. Veronica verna L. - Debrecen: Fancsikai-tavak környékén [8496.3, NT, TA]; Ópályi: ótemető (Rajk László u.) [7999.4, 8099.2, NT, TA].

1646. Veronica dillenii Crantz - Boldogkőváralja: Vár-hegy [7693.3, NT, TA].

1650. Veronica praecox All. - Abaújszántó: Sátor-hegy, szőlők között illetve Gyűr-tető, bolygatott felszínen (vaddisznó túrás?) [7793.1, TA, NT, MVA]; Boldogkőváralja: Vár-hegy [7693.3, NT, TA].

1656. Veronica persica Poir. - Borsodbóta: temető [7788.3, TA, NT, MVA]; Csorvás: Micsurin utcai temető [9391.3, TA, NT, MVA]; Hetes: az iskola melletti parkban [9572.3, NT, TA]; Köröstarcsa: temető [9192.1, TA, NT, MVA]; Nagyszénás: temető [9389.2, TA, NT, MVA]; Nekézseny: temető [7888.2, TA, NT, MVA]; Székkutas: temető [9589.1, TA, NT, MVA]; Taktabáj: temető [7993.2, NT, TA]; Tiszaladány: temető [7994.1, NT, TA].

1671. Odontites vernus (Bellardi) Dumort. - Berettyóúffalu: Tardi-szik [8795.3, SG, TA, MVA].

1678. Lathraea squamaria L. - Gyenesdiás: Csider-völgy [9269.2, NT, TA]; Tokaj: Lencsésvölgy [7894.3, TA].

1718. Asperula cynanchica L. - Sajóhídvég: temető [7991.4, MVA, TA].

1723. Galium boreale L. - Szolnok: Szandai-nagy-rét [8887.1, MVA, TA]; Tapolca: Felső Köles-dúlő [9170.2, MVA, TA].

1724. Galium rubioides L. - Sződliget: Duna menti töltésen [8280.4, LBA, MVA, TA].

1725. Galium rivale (Sibth. et Sm.) Griseb. - Regéc: a Cserenkő forrása közelében [7594.3, TA].

1728. Galium glaucum L. - Harkány: Terehegyi kőbánya [0175.1, MVA, TA].

1747. Cruciata pedemontana (Bellardi) Ehrend. - Tépe: Körtélyes [8695.3, TA]; Tihany: Apáti-tető [9073.3, MVA, TA].

1748. Cruciata laevipes Opiz - Garbolc: Hármashatár [8003.1, TA]; Miskolc: Létrás-tető [7889.3, FR].

1749. Cruciata glabra (L.) Ehrend. - Nyírábrány: Kis-Mogyorós erdő [8498.1, PWP].

1758. Plantago media L. - Nemesbikk: a Szúnyog-domb alatt [8191.2, MVA, TA].

1778. Valerianella rimosa Bastard - Balatonkenese: Soós-hegy [8974.4, MVA, TA].

1788. Succisa partensis Moench - Kurityán-Sajókaza: Kurityán-tető és Kétes-tető közötti felhagyott szőlőkben [7689.4, MÁ].

1800. Campanula sibirica L. - Balatonfüred: Tamás-hegy [9073.1, MVA, TA].

1806. Campanula rapunculoides L. - Gönc: Nagy-Bostyán [7593.2, TA].

1828. Aster linosyris (L.) Bernh. - Berettyóújfalu: Tardi-szik [8995.3, LKÁ, MVA, SG, TA].

1829. Aster sedifolius L. - Berettyóújfalu: Tardi-szik [8795.3, SG, TA, MVA].

1845. Micropus erectus L. - Balatonfüred: Tamás-hegy [9073.1, MVA, TA].

1847. Gnaphalium uliginosum L. - Konyár: Bodzás [8695.4, MVA, LKÁ, SG]. 
1852. Inula conyza DC. - Jászágó: telepített nyarasban, a falutól DK-re [8485.1, TA]; Jászárokszállás: Jászágó felé, telepített nyarasban [8385.3, TA].

1858. Inula ensifolia L. - Bőcs: üzemvíz csatorna menti depónián [7991.4, TA]; Gönc: NagyBostyán [7593.2, TA].

1885. Galinsoga ciliata (Raf.) S.F. Blake - Tiszaroff: Szilvási-dűlőút [8588.3, TA].

1894. Anthemis tinctoria L. - Tokaj: a Hétszőlő fölötti sztyepréteken [7894.3, TA].

1903. Achillea setacea Waldst. et Kit. - Litér: Mogyorós-hegy [8974.1, MVA, TA].

1922. Artemisia annua L. - Debrecen: a Debreceni Vízmű épülete mögötti parkolóban (Pásti és Piac u. között) [8495.4, SK]; Tiszaroff: Szilvási-dűlőút [8588.3, TA].

1938. Erechtites hieracifolia (L.) Raf. ex DC. - Keszthely: Büdöskúti út [9269.2, TA]; Telkibánya: Ósva-völgy [7594.1, TA].

1945. Senecio viscosus L. - Regéc: Hosszú-kő [7594.3, TA].

1946. Senecio vernalis Waldst. et Kit. - Bőcs: vasútállomás [7991.2, TA]; Bölcske: a falu É-i részén, szőlők közt [9279.4, NT, TA]; Debrecen: vasútállomás [8495.4, TA]; Dunaföldvár: temető (Paksi u.) [9279.2, NT, TA]; Előszállás: temető [9178.4, NT, TA]; Erdőbénye: Fáslegelő [8497.3, MVA]; Hajdúnánás-Tedej: belterület, vasúti átjáró [8094.3, NT, TA]; IzsákKisizsák: Reviczky u. [9182.3, NT, TA]; Karcag: Apavára, vasúti sínek mentén [8692.3, NT, TA]; Kisvárda: Akácfa utcai temető [7798.4, NT, TA]; Mezőszilas: temető (Rákóczi Ferenc u.) [9176.4, NT, TA]; Onga: vasútállomás [7891.3, NT, TA]; Simontornya: temető [9277.3, NT, TA]; Solt: temető [9179.4, NT, TA]; Szedres: tengelic felé, vasúti átjárónál, kőzútalékon [9578.1, NT, TA]; Szeged: vasútállomás [9786.4, SK]; Szerencs: belterület, vasúti átjáró Dobó Katica út) [7893.1, NT, TA]; Tengelic: temető [9478.3, NT, TA]; Tiszalök: belterület, vasúti átjáró (Kossuth u.) [7994.3, NT, TA]; Tiszaújváros: vasútállomás [8092.3, SK]; Tiszavasvári: belterület, az Alkaloida előtti iparvágányok között [8094.3, NT, TA]; Újszász: vasútállomás [8786.1, NT, TA].

1948. Senecio erucifolius L. - Berettyóújfalu: Tardi-szik [8795.3, SG, TA, MVA].

1957. Senecio doria Nath. - Nagykőrös: Nagykőrösi-erdő, a Szurdoktól É-ra [8984.1, MVA, TA].

1969. Arctium minus (Hill) Bernh. - Jászágó: Jászárokszállás felé, út menti nyarasban [8485.1, TA].

1984. Cirsium brachycephalum Jur. - Hajdúvid: Fekete-dúlő [8295.1, NT, TA].

1988. Cirsium rivulare (Jacq.) All. - Bagamér: Kék-kálló-völgye [8497.4, LBA]; Nyírábrány: Szentannapuszta [8497.2, LBA]; Nyírábrány: Mogyorós [8498.1, MVA]; Újléta: Kapott-tag [8597.1, FR]; Újléta: Nagy-Ócsa [8597.3, FR]; Zalaszántó: a Nagy-réti-patak és a Büdös-kútidúlő közötti réten [9169.2, MVA, TA].

2000. Centaurea indurata Janka - Püspökladány: vasút mentén egyetlen tô, még a pályafelújítás előtt [8692.4, TA]; Tokaj: a Tokaji-hegy északi lejtőin, kaszálógyümölcsösökben [7894.3, TA].

2003. Centaurea cyanus L. - Enying-Balatonbozsok: Kétcsapás-közi-dűlő [9075.3, NT, TA]; Kánya: Tab felé, repceföld szélén [9274.3, NT, TA]; Simontornya: temető [9277.3, NT, TA]; Tiszalúc: Tiszadob felé, gabonaföld szegélyében [7992.4, TA].

2016. Hypochoeris maculata L. - Balatonfüred: Tamás-hegy [9073.1, MVA, TA]; Kislengyel: temető [9266.1, MVA, TA].

2024. Podospermum canum (C.A. Mey.) Griseb. - Enying-Balatonbozsok: Kétcsapás-közidűlő [9075.3, NT, TA]; Várpalota: Rétipuszta, bánya [8875.1, MVA].

2026. Scorzonera purpurea L. - Tállya: Patócs-hegy [7793.3, TA].

2028. Scorzonera austriaca L. - Erdőbénye: Mulató-hegy [7794.1, TA]; Tállya: Patócs-hegy [7793.3, TA].

2037. Sonchus palustris L. - Tornyosnémeti: Hosszú-rét K-i része [7493.4, MÁ].

2048. Taraxacum serotinum (Waldst. et Kit.) Poir. - Enying-Balatonbozsok: Kétcsapásközi-dűlő [9075.3, NT, TA]. 
2049. Taraxacum laevigatum agg. - Abaújszántó: Sátor-hegy [7793.1, TA, NT, MVA]; Erdőbénye: Mulató-hegy [7794.1, TA, NT, MVA].

2070. Hieracium cymosum L. - Balatonfüred: Tamás-hegy [9073.1, MVA, TA]; Sajóhídvég: temető [7991.4, MVA, TA].

2123. Alisma gramineum Lej. - Hajdúböszörmény: Magi-dűlő, belvizes folton [8293.2, LV, MVA, TA].

2125. Alisma lanceolatum Withering - Konyár: Bodzás [8695.4, MVA, LKÁ, SG]; Prügy: Görgő-gyep [7993.2, TA].

2149. Colchicum autumnale L. - Bedő: Nagy-láp [8795.3, LKÁ, MVA, SG, TA]; Dobronhegy: Kandikó [9166.3, MVA, TA]; Kismarja: a falu NY-i szélén [8796.4, LKÁ, MVA, SG, TA].

2153. Ornithogalum boucheanum (Kunth) Asch. - Cigánd: temető [7797.1, NT, TA]; Ilk: ótemető [7899.3, NT, TA]; Soldostelep: temető [7788.1, TA, NT, MVA]; Tiszaújváros: Mátyás Király u. [8092.3, SK].

2162. Scilla kladnii Schur - Garbolc: Hármashatár [8003.1, TA].

2167. Muscari tenuiflorum Tausch - Harkány: Terehegyi kőbánya [0175.1, MVA, TA].

2169. Muscari neglectum Guss. ex Ten. - Márokpapi: belterület, árokpart [7801.3, PWP]; Nagykőrös: Nagykőrösi-erdő, a Szurdoktól É-ra [8984.1, MVA, TA].

2184. Allium atropurpureum - Mindszent: a falutól K-re, út menti facsoport alatt [9487.3, MVA, TA].

2188. Allium oleraceum L. - Gönc: Nagy-Bostyán [7593.2, TA].

2198. Asparagus officinalis L. - Nyírábrány: Teleki-legelő [8498.1, PWP].

2204. Potamogeton acutifolius Link - Olaszliszka: Füzes-tó [7794.4, TA].

2289. Luzula campestris (L.) DC. - Debrecen: Fancsikai-tavak környékén [8496.3, NT, TA].

2222. Gagea pratensis (Pers.) Dumort. - Berettyóújfalu: Nagy-Bócs [8895.1, TA, NT, MVA]; Darvas: temető [8894.3, TA, NT, MVA]; Ilk: ótemető [7899.3, NT, TA]; Köröstarcsa: temető [9192.1, TA, NT, MVA]; Nyírmada: ótemető [7999.1, NT, TA]; Ófehértó: Korhányi-erdő [8098.3, NT, TA]; Rohod: temető [7998.4, NT, TA]; Soldostelep: temető [7788.1, TA, NT, MVA]; Taktabáj: ótemető [7993.2, TA]; Tarcal: Kápolna [7894.3, TA]; Tiszaladány: temető és Tiszatardos felé az út mentén [7994.1, NT, TA]; Tiszatardos: parlagon [7994.3, NT, TA]; Tiszatardos: komp fölötti töltésen, valamint belterületen az ótemetőben [7994.3, NT, TA].

2223. Gagea lutea (L.) Ker Gawl. - Abaújszántó: Aranyos-völgy [7793.1, MVA, TA, NT]; Magosliget: Fischer-erdő [7903.1, MVA].

2226. Gagea spathacea (Hayne) Salisb. - Magosliget: Fischer-erdő [7903.1, MVA].

2227. Gagea villosa (M. Bieb.) Duby - Boldogkőváralja: temető [7693.3, NT, TA]; Borsodbóta: temető [7788.3, TA, NT, MVA]; Bőcs: sörgyár előtt, járda menti gyepsávban [7991.2, TA]; Csobaj: a református templom kertjében [7994.3, NT, TA]; Furta: temető melletti parlag [8894.4, TA, NT, MVA]; Köröstarcsa: temető [9192.1, TA, NT, MVA]; Lácacséke: temető [7697.2, TA, NT, MVA]; Mád: temető [7893.2, MVA, NT, TA]; MedinaSzőlőhegy: temető [9577.2, NT, TA]; Sajómercse: temető [7788.3, TA, NT, MVA]; Soldostelep: temető [7788.1, TA, NT, MVA]; Zádorfalva: temető [7688.2, TA, NT, MVA].

2241. Galanthus nivalis L. - Tokaj: a Tokaji-hegy É-i lejtőin [7894.3, TA].

2254. Iris sibirica L. - Erdőbénye: Alsó-rétek [7794.3, TA]; Létavértes: Falu-rét [8697.1, FR, LKÁ, MVA]; Nyirád: Sárálló [8970.3, MVA, TA]; Szécsény: Káprás-alja [7982.2, MVA]; Tapolca: Felső Köles-dűlő [9170.2, MVA, TA].

2259. Iris aphylla L. subsp. hungarica (W. et K.) Hegi - Sajókaza: Kétes-tető déli nyúlványán, régen felhagyott szőlők helyén (Stipa dasyphylla társaságában) [7789.2, MÁ].

2264. Crocus heuffelianus Herb. - Garbolc: Hármashatár [8003.1, LBA].

2276. Juncus tenuis Willd. - Makkoshotyka: Pusztavár [7695.1, KJ, LKÁ, TA].

2283. Juncus atratus Krock. - Füzér: Drahos [7494.2, TA].

2284. Juncus articulatus - Zalaegerszeg: homokbánya [9167.3, MVA]. 
2299. Festuca heterophylla Lam. - Erdőbénye: a Fás-legelő mellett, gyertyános-tölgyesben [7793.2, TA].

2322. Vulpia myurus (L.) C.C. Gmel. - Gyenesdiás: Malom u., nádast átszelő dolomit úton [9269.2, NT, TA]; Mikepércs: Bocskai utcai belterületi ingatlan kertjében [8595.4, SG].

2331. Poa trivialis L. - Tiszaderzs: Cserőközi Holt-Tisza [8489.4, MVA, TA, SG].

2355. Melica ciliata L. - Tokaj: a Tokaji-hegy csúcsa [7894.3, TA]; Veszprém: Kádárta felé [8873.4, MVA].

2356. Melica transsilvanica Schur - Hídvégardó: Kecske-vár [7491.1, LBA, EVA, SK].

2373. Bromus secalinus L. - Alsószuha: Alsó-rét [7689.1, NT, TA].

2380. Bromus erectus Huds. - Nemesbikk: Álomzugi-gyep [8191.2, TA].

2404. Secale sylvestre Host - Nagykőrös: Nagykőrösi-erdő tisztásán [8984.1, TA].

2420. Helictotrichon pubescens (Huds.) Pilg. - Kapoly: a Bőcse É-i lejtőin [9273.4, NT, TA].

2422. Helictotrichon adsurgens (Schur ex Sim.) Con. - Bekecs: Közép-hegy [7893.1, TA]; Erdőbénye: Mulató-hegy [7794.1, SG].

2434. Trisetum flavescens (L.) P. Beauv. - Zalaszántó: a Nagy-réti-patak és a Büdös-kútidűlő közötti réten [9169.2, TA].

2441. Anthoxanthum odoratum L. - Dobronhegy: Kandikó [9166.3, MVA, TA]; Monostorpályi: a falutól ÉK-re elterülő gyepek [8596.4, TA]; Nemesbikk: a Szúnyog-domb alatt [8191.2, MVA, TA]; Nyírábrány: Szentannapuszta [8497.2, LBA]; Tiszadob: a Tisza jobb parti töltésén [7992.4, TA]; Tiszaladány: a Holt-Tisza (Kis-Tisza) által körülvett terület kaszálórétjein [7994.2, TA].

2471. Milium effusum L. - Nyírábrány: Mogyorós [8498.1, MVA].

2476. Stipa dasyphylla (Czern. ex Lindem.) Trautv. - Tállya: Patócs-hegy [7793.3, TA].

2479. Stipa pulcherrima K. Koch - Balatonfüred: Tamás-hegy [9073.1, MVA, TA].

2487. Cleistogenes serotina (L.) Keng - Gönc: Nagy-Bostyán [7593.2, TA].

2489. Eragrostis cilianensis (All.) Vignolo ex Janch. - Keszthely: Szendreytelepi út, járda repedéseiben [9269.1, NT, TA].

2496. Crypsis alopecuroides (Piller et Mitterp.) Schrad. - Konyár: Bodzás [8695.4, MVA, LKÁ, SG].

2499. Tragus racemosus (L.) All. - Hajdúböszörmény-Görbeháza: a két települést összekötő út padkáján [8293.2, LV, MVA, TA]; Hajdúnánás: vasútállomás [8194.4, NT, TA]; Látrány: temető [9272.1, LV, MVA].

2501. Leersia oryzoides (L.) Sw. - Lakitelek: Tiszaug-hídfő [9186.1, TA]; Telkibánya: Ósvavölgy [7594.1, TA].

2504. Panicum capillare L. - Keszthely: Büdöskúti út [9169.4, TA].

2515. Setaria viridis (L.) P. Beauv. - Gönc: Nagy-Bostyán [7593.2, TA].

2518. Sorghum halepense (L.) Pers. - Debrecen: Vénkert [8495.4, SK].

2530. Lemna trisulca L. - Újléta: Új-Ócsa [8597.3, FR].

2549. Schoenoplectus supinus (L.) Palla - Konyár: Bodzás [8695.4, MVA, LKÁ, SG]; Tiszaderzs: Sulymos [8489.4, MVA, TA, SG].

2561. Scirpus sylvaticus L. - Monostorpályi: Damjanich utca vége [8696.2, MVA, LKÁ].

2568. Eleocharis acicularis (L.) Roem. et Schult. - Tiszaderzs: Sulymos [8489.4, MVA, TA, SG].

2572. Eleocharis uniglumis (Link) Schult. - Kesznyéten: Majorsági-dűlő [8092.1, NT, TA]; Létavértes: Falu-rét [8697.1, MVA, LKÁ].

2576. Dichostylis micheliana (L.) Nees - Lakitelek: a Tiszaug-hídfőtől D-re [9186.1, MVA].

2578. Cyperus flavescens L. - Nyirád: Melegvíz partja [9070.2, MVA].

2579. Cyperus fuscus L. - Lakitelek: a Tiszaug-hídfőtől D-re [9186.1, MVA].

2581. Cyperus glomeratus L. - Lakitelek: a Tiszaug-hídfőtől D-re [9186.1, MVA].

2594. Carex brizoides L. - Hernyék: Mumor felé, műút menti árokban [9365.4, MVA, NT, TA].

2596. Carex elongata L. - Füzér: Drahos [7494.2, TA]; Hernyék: Mumor felé, műút menti árokban [9365.4, MVA, NT, TA]. 
2599. Carex spicata Huds. - Hernyék: Mumor felé, műút menti árokban [9365.2, MVA, TA]; Monostorpályi: Damjanich utca vége [8696.2, MVA, LKÁ]; Nemesbikk: a Szúnyog-domb alatt [8191.2, MVA, TA].

2600. Carex pairaei F. W. Schultz - Taktakenéz: Szent-erdő [7993.3, TA].

2606. Carex disticha Huds. - Kesznyéten: Sárrét-puszta [8092.1, MVA, TA]; Létavértes: Falurét [8697.1, MVA, LKÁ].

2610. Carex elata All. - Bagamér: Kék-kálló-völgye [8497.4, LBA]; Becsvölgye: a Kislengyelipatak mentén [9266.1, MVA, TA]; Nyirád: Sárálló [9070.2, MVA, TA]; Tapolca: Felső-Kölesdűlő [9170.2, MVA, TA].

2611. Carex acuta L. - Bagamér: Kék-kálló-völgye [8497.4, LBA]; Kesznyéten: Sárrét-puszta [8092.1, MVA, TA]; Nyírábrány: Mogyorós [8498.1, MVA]; Újléta: Kapott-tag [8597.1, FR].

2612. Carex nigra (L.) Reichard - Füzér: Drahos [7494.2, TA]; Szemere: Rakaca-patak forrásvidéke [7592.2, TA].

2613. Carex buekii Wimm. - Erdőbénye: Nagy-rétek [7794.1, NT, TA]; Kurityán: Csörgőspatak mentén [7689.4, TA]; Pálháza: Kormos-rét [7595.1, KJ].

2615. Carex hartmanii Cajander - Létavértes: Falu-rét [8697.1, MVA, LKÁ]; Nyirád: Sárálló [8970.3, MVA, TA].

2621. Carex flacca Schreb. - Cegléd: Csíkos-szél [8884.2, MVA, TA]; Villány: Templom-hegy [0176.2, MVA, TA]; Zalaegerszeg: homokbánya [9167.3, MVA].

2625. Carex caryophyllea Latourr. - Dunatetétlen: Dög-szék [9280.4, MVA, TA]; Hernyék: Zsohár-fenyős [9365.2, MVA, TA]; Monostorpályi: a falutól ÉK-re elterülő gyepek [8596.4, TA].

2626. Carex tomentosa L. - Létavértes: Falu-rét [8697.1, MVA, LKÁ]; Monostorpályi: Damjanich utca vége [8696.2, MVA, LKÁ]; Ózd: Táblai temető [7787.4, MVA, SK]; Zalaszántó: a Nagy-réti-patak és a Büdös-kúti-dűlő közötti réten [9169.2, MVA, TA].

2629. Carex ericetorum Pollich - Pilisszentiván: Kis-Szénás [8379.3, TA].

2633. Carex pseudocyperus L. - Nyírábrány: Keszler-tag [8498.1, MVA]; Újléta: Új-Ócsa [8597.3, FR].

2634. Carex sylvatica Huds. - Tiszaújváros: Középső-rétek, töltés menti telepített tölgyesben [8092.3, TA].

2636. Carex pallescens L. - Kerkabarabás: Szemerelakos [9365.1, MVA, TA]; Nova: a Makkosi-hegy D-i lábánál [9266.3, MVA, TA].

2638. Carex acutiformis Ehrh. - Nemesbikk: Horváth-tag [8192.1, TA].

2641. Carex vesicaria L. - Füzér: Drahos [7494.2, TA].

2642. Carex melanostachya Willd. - Hajdúnánás: Veres-tenger-dűlő [8194.1, NT, TA].

2644. Carex liparicarpos Gaudin - Cserszegtomaj: Gyötrös-tető [9269.2, TA]; Cserszegtomaj: Gyötrös-tető [9269.2, MVA, TA]; Fülöpszállás: temető [9181.3, NT, TA]; Nagykőrös: Nagykőrösi-erdő tisztásán [8984.1, TA].

2645. Carex panicea L. - Cegléd: Csíkos-szél [8884.2, MVA, TA]; Dunaszeg: Nádas-tó [8271.1, MVA, TA]; Kiskőrös: Város feletti kaszáló [9381.4, MVA, TA]; Nemesbikk: Álomzugi-gyep [8191.2, TA]; Nova: a Makkosi-hegy D-i lábánál [9266.3, MVA, NT, TA]; Nyirád: Sárálló [8970.3, MVA, TA]; Zalaszántó: a Nagy-réti-patak és a Büdös-kúti-dúlő közötti réten [9169.2, MVA, TA].

2653. Carex viridula Michx. - Cegléd: Csíkos-szél [8884.2, MVA, TA]; Kővágóörs: Keleti Kőhát I. bánya [9171.2, MVA].

2656. Carex distans L. - Cegléd: Csíkos-szél [8884.2, MVA, TA]; Dunaszeg: Nádas-tó [8271.1, MVA, TA]; Dunaszeg: bányató partján [8271.1, MVA, TA]; Kiskőrös: Város feletti kaszáló [9381.4, MVA, TA]; Penészlek: Peces-tó [8399.3, LBA]; Zalaszántó: a Nagy-réti-patak és a Büdös-kúti-dúlő közötti réten [9169.2, MVA, TA].

2661. Epipactis voethii Robatsch - Diósjenő: Hárombarát-nyereg [8079.2, MÁ]; Kemence (Királyháza): Dobó-bérc alján, a Tűzköves-forrás közelében [8079.2, MÁ]. 
2678. Limodorum abortivum (L.) Sw. - Kemence: Miklós-tető oldalában a zöld sáv turistaút mentén [8079.1, MÁ].

2705. Orchis militaris L. - Kurityán: Kurityán-tető délnyugati oldalában [7689.4, MÁ].

2709. Anacamptis palustris (J.) Bateman et al. - Izsák: Balázs-dúlő [9181.2, MVA, TA].

\section{Helyreigazítás}

A Magyarország edényes növényfajainak elterjedési atlaszában (BARTHA et al. 2015: 7.) olvasható, hogy a Magyarország veszélyeztetett hajtásos növényeinek ritkasága, életmenetjellemzối és klímaválasza című OTKA pályázat keretében három herbáriumból (BP, DE, EGR) 84 faj esetében gyűjtött adatok kódolásra és beépítésre kerültek. Az adatbázis készítőiként azonban az adatbázis alapjául szolgáló digitális fényképeket készítők (Löki Viktor, Ljubka Tibor, Lovas-Kiss Ádám, Süveges Kristóf és Freytag Csongor) neve jelent meg. Az adatbázist valójában Nótári Krisztina, Szatmári Lajos, Takács Attila, E. Vojtkó Anna és Molnár V. Attila hozták létre.

\section{Köszönetnyilvánítás}

Hálásak vagyunk Bartha Dénesnek, Schmidt Dávidnak és Tiborcz Viktornak a kézirat lektorálásáért és hasznos észrevételeikért. A kutatás a TÁMOP-4.2.4.A/2-11/1-2012-0001 és TÁMOP-4.2.2.B-15/1/KONV-2015-0001 programok keretében, az OTKA K108992 pályázat támogatásával valósult meg. Takács Attila munkáját a Nemzeti Tehetség Program Egyedi fejlesztést biztosító ösztöndíja (NTP-EFÖ-P-15) támogatta. Malatinszky Ákos munkáját a Kutató Kari Kiválósági Támogatás (11476-3/2016/FEKUT) segítette.

\section{Irodalom}

Bartha D., Király G., Schmidt D., Tiborcz V., Barina Z., Csiky J., Jakab G., Lesku B., Schmotzer A., VidéKi R., VojtKó A. \& ZóLYomi Sz. (szerk.)(2015): Magyarország edényes növényfajainak elterjedési atlasza. Nyugat-magyarországi Egyetem Kiadó, Sopron, 329 pp.

FEKETE G. (2011): Florisztika ma és holnap. - Kitaibelia [2010] 15: 13-23.

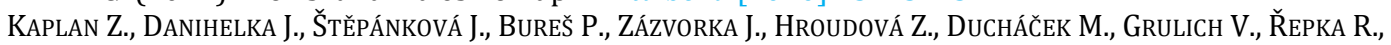
Dančák M., PrančL J., Šumberová K., Wild J. \& TrávníčEK B. (2015): Distributions of vascular plants in the Czech Republic. Part 1. - Preslia 87: 417-500.

Kaplan Z., Danihelka J., ŠTĚPÁnková J., Ekrt L., Chrtek J. JR., Zázvorka J., Grulich V., Řepka R., PranČL J., DucháčEK M., KúR P., Šumberová K. \& BRŮna J. (2016): Distributions of vascular plants in the Czech Republic. Part 2. - Preslia 88: 229-322.

KIRÁLY G. (szerk.) (2009): Új magyar füvészkönyv. Magyarország hajtásos növényei. Határozókulcsok. Aggteleki Nemzeti Park Igazgatóság, Jósvafő.

KIRÁLY G. et al. (2003): A magyarországi flóratérképezés módszertani alapjai. Útmutató és magyarázat a hálótérképezési adatlapok használatához. - Flora Pannonica 1: 3-20.

Kull T., KuKK T., LehT M., KRAll H., KuKK Ü., Kull K. \& KuUSK V. (2002): Distribution trends of rare vascular plant species in Estonia. - Biodiversity \& Conservation 11 (2): 171-196.

Pócs T. (2016): Könyvismertetés. - Botanikai Közlemények 103 (1): 117-118.

Beérkezett / received: 2016. 06. 01. • Elfogadva / accepted: 2016.06. 25. 